\title{
DESCRIPTIONS OF NEW SPECIES OF MINUTE MARINE SHELLS FROM BOMBAY.
}

\author{
By J. Cosmo Melvill, M.A., F.L.S., etc. \\ Read 10th April and 8th May, 1896. \\ PLATE VIII.
}

In November, 1892, conjointly with Mr. Alexander Abercrombie, of Bombay, I published ${ }^{1}$ a Catalogue of about 320 species of marine Mollusca, that had been collected by the latter gentleman during three successive seasons on the shores of this favoured, specialized, and little explored centre. Specialized, Bombay is certainly proved to be in this particular, since many showy species would seem to have made her coasts their headquarters; and, besides, in the Catalogue just referred to, no less than twenty-five were signalized as novelties, many belonging to the more attractive genera, e.g., Purpura, Murex, Tellina, and Raëta. At the same time a few of the "minutiora" were described and figured, and a far larger number set aside for future investigation. These have received welcome additions by an assortment of two further boxes of shell-shingle, kindly forwarded a year ago by $\mathrm{Mr}$. Abercrombie; which, while yielding further specimens of nearly all the smaller species first enumerated, likewise provided fresh material in the way of many novelties.

The molluscan fauna of Bombay being, as already observed, well differentiated and specialized, it is rendered a simpler task than might be thought, to discriminate such forms as are now to be described. No dredgings, scientifically made, have been carried out here-indeed, I am informed, the configuration of these coasts is not satisfactory for the purpose-and no collections of the smaller species, excepting a few by the Rev. Mr. Fairbank, of Bombay, and Messrs. H. F. and W. T. Blanford, had been made, when a few species, e.g. Irawadia trochlearis, Blanf., and Fairbankia Bombayana, Blanf., were described. Mr. Geoffrey Nevill subsequently discovered a few, mainly Pleurotomidæ, and it is regrettable that his types are all in the Calcutta Museum, and therefore inaccessible to most British conchologists. Some, however, have been figured in the Journal of the Asiatic Society of Bengal.

The Ceylon fauna and that of Karachi, the latter now being assiduously explored by Mr. F. W. Townsend, differ widely from that of Bombay, though of course a few species are common to two or all three of the localities. We cannot think that, numerically, the Bombay list will exceed 500 species (exclusive of brackish-water forms such as Neritina, Potamides, etc.); and the publication of the following twenty-six new forms, mainly belonging to the families

1 Cf. Memoirs Manchester Lit. and Phil. Soc., series Iv, vol. vii, pp. 17-51. 
Solariidæ, Scalariidæ, Pyramidellidæ, and Cerithiidæ, will swell up the total of those catalogued to 350 species.

I would tender my best thanks, not only to $\mathrm{Mr}$. Abercrombie, for oroviding the material of which this paper is the outcome, but also to Mr. E. A. Smith and Mr. E. R. Sykes, for aid and advice. It is my intention to offer to place the types of all these small species in the Natural History Museum, South Kensington.

\section{Bittium tenthrenoïs, n.sp. Pl. VIII, Fig. 1.}

B. testa cylindrica, obesula, doliiformi, solida, ochracea, apice obtuso, apud apicem, simul ac ad basim pallidiore, anfractibus 7 , in medio latioribus, tribus papillarum ordinibus transversim regulariter instructis, papillis parvis, gemmatis, interstitiis alveolatis, apertura svato-rotunda, labro exteriore minime expanso. Long. 3, lat. 1.25 mm.

About twenty specimens of a small, tun-shaped, cylindrical shell, warm ochraceous in colour, with the extremities pale, almost white, ornamented with three rows of papilliform gemmæ on the whorls, the spaces between them being alveolate, whence the specific name, derived from $\tau \epsilon \nu \theta \rho \eta \nu \dot{w} \eta \mathbf{s}$, 'honeycombed.' This species is slightly like Cerithiopsis pulvis, Issel, from the Red Sea, a very small species, which, with the present one, I should be inclined to class rather as a Bittium.

\section{Cerithiopsis rubricincta, n.sp. Pl. VIII. Fig. 15.}

C. testa fusiformi, solida, pallide ochracea, anfractibus 10 vel 11, tumidis, apud suturas impressis, binis gemmarum ordinibus transversim decoratis, longitudinaliter clathratis, interstitiis alveolatis, infra juxta suturas tenui rubra zona accinctis, apertura subrotunda, peristomate tenui, canali brevi. Long. $3.25 \mathrm{~mm}$. sp. maj., lat. $1 \mathrm{~mm}$.

Very beautiful, though minute. Of a pale ochraceous colour; the ventricose whorls are ornamented, just below the sutures, with a red band; the sculpture is, as is usual amongst the Triforis, Bittium, and Cerithiopsis, a double row of transverse gemmæ, crossed by latticeforming riblets, the interstices being honeycombed and deep. The mouth is almost round, canal very short, lip simple. Several specimens.

\section{Cerithiopsis Sykesir, n.sp. Pl. VIII, Fig. 8.}

C. testa attenuato fusiformi, aciculata, ochracea, anfractibus 12 vel 13, rectis, minime ventricosulis, trinis gemmarum papilliformium ordinibus transversim cingulatis, apud suturas impressis, in uno specimine juveni duobus apicalibus anfractibus pellucidis, vitreis, apertura subquadrata, simplice. Long. $4 \cdot 25$, lat. $1 \cdot 20 \mathrm{~mm}$.

A tropical representative of the typical species of the genus, C. tubercularis, Mont., from which this shell differs in being straighter, more attenuate, and regular. It comes nearer to the $C$. diadema, Watson, from Madeira, of which I have only seen a figure, but is smaller than that species. It is of a uniform pale ochraceous-brown, and the single young individual of the series possesses two vitreous apical whorls intact. I have much pleasure in connecting with this small Cerithiopsis the name of Mr. E. R. Sykes, our indefatigable Secretary. 


\section{Cerithiopsis pulcherrima, n.sp. Pl. VIII, Fig. 3.}

C. testa tenui, multum attenuata, aciculari, albida, anfractibus 13 , apud suturas canaliculatis, apud canales uno gemmularum ordine, cæterasque in partes anfractuum bino ordine similari instructis, apertura subquadrata, labro tenui. Long. 4, lat. 1.15 mm.

Seven specimens, mostly rather imperfect. The largest, from which this description is taken, is slightly distorted in one of the central whorls; it is in very good condition, being white, elongated, very attenuate, thirteen-whorled, ornamented with three rows of gemmules, one row being at the canaliculate depression, just below the sutures of each whorl, the other two on the normal whorl. The mouth is simple, aperture squarrose. It is a very beautiful little species.

\section{Solarium (Torinia) homalaxis, n.sp. Pl. VIII, Fig. 12.}

S. testa minutissima, depressa, profunde umbilicata, albescente, gemmulata, supra depresso-planata, anfractibus 4, ultimo rapide accrescente, ad peripheriam bicarinato, carinis regulari gemmarum ordine decoratis, simili bino ordine circa umbilicum, inter has, infra, simul ac supra, quatuor minorum gemmularum ordinibus instructis, apertura quadrato-rotunda. Long. 1, lat. $2 \mathrm{~mm}$.

I alluded to this specimen when describing its congener, S. delectabile, also from the same locality. ${ }^{1}$ This species differs in its more depressed form, the bicarinate angles at the periphery, and its smaller size. The shell is in juvenile condition, however, and may grow slightly larger, the apical whorls showing this. It is an exceedingly highly chased and sculptured little species.

\section{Rissoina epentroma, n.sp. Pl. VIII, Fig. 23.}

R. testa ovata, gradata, solidiuscula, candida, anfractibus 5, undique longitudinaliter crassicostatis, costis lævibus, interstitiis transversim tenuistriatis, apertura ovata, labro exteriore incrassato. Long. 2, lat. $1 \cdot 15 \mathrm{~mm}$.

Three specimens, one being juvenile, of a highly sculptured little species, which I have placed in Rissoina rather than in Rissoia, owing to the thickened base of the aperture, the general form being more in accordance with a species of the latter genus.

The shell is gradately turreted, five-whorled, the whorls being uniformly costate, the ribs very thick in proportion to the size of the shell, and the interstices between transversely finely striate. The

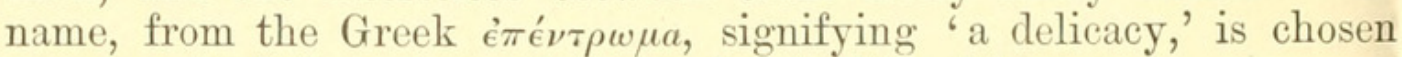
on account of the extreme beauty of this little Rissoina.

\section{Rissoina pachystoma, n.sp. Pl. VIII, Fig. 4.}

R. testa solida, fusiformi, albo-cinerea, anfractibus 8, undique longitudinaliter recticostatis, costis regularibus, lævibus, nitentibus, interstitiis lævibus, apertura oblique ovata, labro exteriore multum incrassato, ad basim quasi-truncato, margine columellari obliquo, crasso. Long. 5, lat. $2 \mathrm{~mm}$.

1 Mem. Manch. Lit. and Phil. Soc., vol. vii, p. 57. 
The nearest approach to this species seems to be $R$. conifera (Schwartz). It is principally distinguishable by its straight, smooth ribs, and extremely incrassate outer lip, the base being somewhat truncate, and the thickening extending to the columellar margin.

\section{Adeorbis vanikoroides, n.sp. Pl. VIII, Fig. 14.}

A. testa profunde umbilicata, depresso-globosa, apice exserto, tenui, anfractibus 4, ultimo rapide accrescente, longitudinaliter obliquissime tenuicostatis, costis lævibus, interstitiis sub lente striatulis, ultimo circa umbilicum effosso, angulari, apertura ovata, labro exteriore simplice, paullulum incrassato. Long. 1.50, lat. $1 \mathrm{~mm}$.

Extremely small, but very characteristic. Of the same character as A. scaber, Phil., a Central American shell, but differing entirely in form; the apex is conspicuously exserted so far as the first two whorls are concerned, the last whorl is large, and entirely longitudinally obliquely ribbed, the interstices between being very finely striate. The umbilicus is profound, angularly ridged above, and the aperture ovate. The specific name suggests a superficial resemblance in miniature to species of Vanitioro, Quoy and Gaimard, which name has precedence by several years over Narica, Recluz.

\section{Aclis ateneles, n.sp. Pl. VIII, Fig. 10.}

A. testa angusta, attenuata, fusiformi, delicatula, albido-cinerea, anfractibus 6, tumidis, apud suturas impressis, sub lente tenuissime transversim striatulis, apertura ovata, labro exteriore paullulum incrassato. Long. 3.25, lat. $1 \cdot 25 \mathrm{~mm}$.

A finely striolate species, with ventricose whorls, six in number, apex obtuse, mouth ovate, simple. The name suggested is the Greek

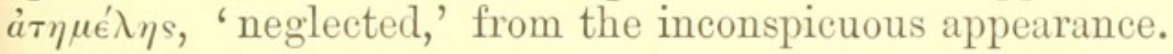

\section{AClis EOA, n.sp. Pl. VIII, Fig. 18.}

A. testa oblongo-fusiformi, delicatula, semipellucida, lactea, apice obtuso, anfractibus 6, paullum ante apicem irregularibus, ventricosis, apud suturas multum impressis, fere lævibus, vix nitentibus; apertura ovata, peristomate simplice, tenui, margine columellari obliquo. Long. $3 \cdot 50$, lat. $1 \cdot 25 \mathrm{~mm}$.

A thin, semipellucid, milky shell, without any gloss, six-whorled, the whorls a little irregular and distorted, ventricose, and impressed at the sutures. The aperture is ovate, the outer lip simple, and the columellar margin somewhat oblique.

It does not yield in beauty to the other known species, nearly all of which are exquisite in form. The specific name is given from its Eastern habitat.

\section{Eulima dens-colubri, n.sp. Pl. VIII, Fig. 19.}

E. testa parva, politissima, attenuato-curvata, apud basim latiore, translucida, anfractibus 10, juxta, infra suturas zona lactea pellucente cinctis, apertura oblique oblonga, labro marginem apud columellarem paullum incrassato. Long. $5 \mathrm{~mm}$. sp. maj., lat. $1.75 \mathrm{~mm}$.

A small incurved species, ten-whorled, smooth, polished, but translucent, the basal portion being broader in proportion. This form is 
allied to the European and British E. incurva, Renieri, E. distorta, Phil. (non Defrance), but the shell is much broader at the base, and the whorls are not so flattened. The mouth is obliquely oblong, and in full-grown specimens the shell is slightly thickened at the columellar margin. Many specimens.

Another small species of Eulima occurs, of which I have two specimens : it is straight, and in form like E. polita, L.; it may possibly be identical with $E$. subangulata, Somb., described as being an inhabitant of the Indian Ocean.

\section{Syrnola metria, n.sp. Pl. VIII, Fig. 16.}

S. testa elongata, fusiformi, solida, alba, nitida, anfractibus 10 , apud suturas acute canaliculatis, rectis, apertura ovato squarrosa, peristomate tenui, simplice, marginem apud columellarem uniplicato. Long. 5, lat. $2 \mathrm{~mm}$.

A shining, smooth species, deeply channelled at the sutures. Mouth squarely ovate, with one columellar plait. In form an Obeliscus, in

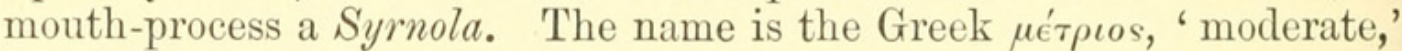
'modest.'

\section{Oscilla Indica, n.sp. Pl. VIII, Fig. 5.}

O. testa attenuata, fusiformi, delicatula, tenui, semipellucida, candida, anfractibus 9 vel 10, transversim undique spiraliter tricostatis, costis acutis lævibus, interstitiis sub lente tenuissime longitudinaliter striatis, apertura oblonga, labro simplice, marginem apud columellarem uniplicato. Long. 3, lat. 1.25 mm.

A very beautiful little form, of which only one specimen has so far occurred. It might easily be overlooked for the young of Irawadia trochlearis, Blanford, but this is a coarser shell, though of the same transversely carinate pattern and white colour. It is a most delicate species, and the columellar plait, though somewhat deep-seated, is very evident.

\section{Mronia gavisa, n.sp. Pl. VIII, Fig. 26.}

M. testa tenuissima, albida, subpellucida, elongato-attenuata, anfractibus 7 , ventricosulis, undique transversim filostriatis, apertura oblonga, peristomate tenui. Long. $2 \cdot 25$, lat. $1 \mathrm{~mm}$.

A very small, delicate species, with some appearance of an Aclis, but we consider rightly referable to Myonia (Actaopyramis, Fischer). The shell is white, subhyaline, whorls probably seven (but the sole specimen is a little broken at the apex), much ventricose, and uniformly transversely filostriate. The name is the Latin gavisus, 'that has given pleasure,' from the beauty and sculpture of this little shell.

\section{Miralda idalina, n.sp. Pl. ViII, Fig. 6.}

M. testa oblonga, gradatula, tenui, albida, subpellucida, anfractibus 6, ad suturas multum impressis, subcanaliculatis, turritis, infra suturas bino gemmarum ordine decoratis, partes ad cæteras anfractuum transversim costulatis, ultimo apud basim læviore, apertura oblonga, labro tenui, marginem ad columellarem uniplicato. Long. 2, lat. $1 \mathrm{~mm}$. 
A very small but well-marked shell, its sculpture being distinct. The whorls, six in number, of which two are very small and apical, one turreted, being much compressed-almost canaliculate-at the sutures. Below the sutures there is a double row of transverse gemmæ, and the rest of the whorls are ornamented with plain, transverse, raised lines or small costæ. The mouth is oblong, and the columellar plait is large and strong.

Only one specimen is in existence, one other, which was in all respects precisely similar, having, unfortunately, got mislaid.

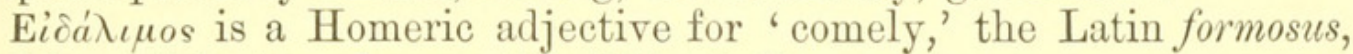
and is well bestowed upon this little shell.

\section{Odostomia antelia, n.sp. Pl. VIII, Fig. 22.}

O. testa ovato-fusiformi, tenui, crystallina, lævi, nitida, anfractibus 6 , apud suturas multum impressis, ventricosulis, sub lente spiraliter tenuissime calcario-lineatis, apertura ovato oblonga, margine columellari uniplicato, plica recta, conspicua. Long. 2, lat. $1 \mathrm{~mm}$.

A typical Odostomia, with translucent, white, polished surface, six whorls, ventricose, deeply impressed at the sutures, giving a gradate appearance to the shell; under a lens in certain strong lights very indistinct, chalky, transverse lines are seen on the surface; the aperture is ovate-oblong, the lip simple, the columellar plait being straight and conspicuous.

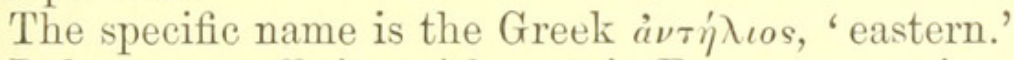

It has some affinity with certain European species, e.g. O. eutimoides and $O$. rissoides, of Hanley.

Another species of Odostomia has, unfortunately, been mislaid. It is a very distinct form, a little larger than the preceding, with the whorls (seven) deeply channelled at the sutures, shape conically fusiform, columella with strong plait, aperture internally spirally striate.

\section{Odostomia syrnolomes, n.sp. Pl. VIII, Fig. 13.}

O. testa attenuata, fusiformi, alba, parum nitente, delicata, anfractibus 6, apud suturas impressis, apertura oblonga, labro fere continuo, marginem apud columellarem fortiter uniplicato. Long. $2 \cdot 50$, lat. $1 \mathrm{~mm}$.

A smooth, dull white, six-whorled little shell, the apex vitreous, mouth ovate, with a strong straight plait on the columellar margin. Like a Syrnola in miniature, hence the specific name. Of the typical form of the genus, allied to O. plicata, Montagu.

\section{Pyrgulna pyrgonella, n.sp. Pl. VIII, Fig. 24.}

P. testa attenuata, fusiformi, gradata, candida, anfractibus 7, ad suturas subimpressis, longitudinaliter, ad medium anfractuum, costulatis, costis lævibus, papillosisque infra juxta suturas, apertura oblonga, labro exteriore simplice, paullum reflexo, columellari conspicue uniplicato. Long. $5 \mathrm{~mm}$. sp. maj., lat. $1.25 \mathrm{~mm}$.

Two specimens of a conspicuously beautiful species, of the same facies as Turbonilla scalaris, Phil., but white, whilst the columellar plait gives it generic distinction. 
The longitudinal ribs begin at a little distance from the sutures, the immediate space between being quite smooth, and the ribs are also slightly papillose at the upper end, the papillæ merging into the rib. The specific name is derived from the Greek $\pi v \rho \gamma \hat{\omega} \mu a$, 'a tower,' from the turreted whorls. It may possibly be equally well placed in the genus Mormula, Ad.

\section{Pyrgulina Edgarit, n.sp. Pl. VIII, Fig. 21.}

P. testa angusta, fusiformi, gradatula, tenui, candida, anfractibus 6 , ad suturas impressis, undique longitudinaliter crassicostulatis, costis scalariformibus, interstitiis transversim tenuissime striatis, apertura ovata, margine columellari fortiter uniplicato. Long. 2 , lat. $\cdot 75 \mathrm{~mm}$.

About twenty specimens. This species I venture to name after Mr. Edgar A. Smith, as a very small token of appreciation for his invariable kindness and assistance. The smaller size, turreted or graduate whorls, thick, longitudinal, scalariform ribs, and extremely fine transverse striations, differentiate this little species from Pyrgulina interstriata, Souverbie, and other allies.

Amongst the Bombay species of this genus, which is sometimes taken as a section of Odostomia, the following occur, in more or less plenty :-

P. callista, Melvill. Twelve of this most beautiful form in the second consignment of shell-sand; only four in the first.

$P$. casta, Adams. A few, not quite typical; may be a different species.

P. interstriata, Souverbie. I cannot separate the most abundant species at Bombay from this. I have specimens from the Gloyne Collection, from Upolu, precisely similar.

P. pyrgomella, n.sp.

P. Edgarii, n.sp.

20. Turbonilla Abercrombiei, n.sp. Pl. VIII, Fig. 7.

T. testa pergracili, attenuata, albida, nitida, anfractibus 11-12, subturritis, omnibus longitudinaliter recticostatis, costis interstitiisque æque lævissimis, anfractu apicali in specimine juvenali, heterostropho, vitreo, apertura subquadrata, peristomate simplice. Long. 4, lat. $1 \mathrm{~mm}$.

Three specimens, of which two are juvenile, showing the apical nucleus, and the third mature, but not quite perfect. Conjecturally, the whorls would be eleven or twelve. The longitudinal ribs are straight, the whole surface is very smooth, and the mouth is square. I have much pleasure in associating with this species the name of my friend Mr. Abercrombie, to whose kindness I am indebted for the whole of the material descanted upon in this paper.

\section{Turbonilla sororia, n.sp. Pl. VIII, Fig. 17.}

T. testa gracili, attenuata, albido-ochracea, semipellucida, tenui, apice heterostropho, anfractibus 11-13, subventricosis; undique longitudinaliter recticostatis, costis, interstitiisque lævissimis, apertura ovata, peristomate simplice. Long. $6 \mathrm{~mm}$. sp. maj., lat. $1 \mathrm{~mm}$.

Several specimens, in various stages of growth; the younger shells 
all showing the mammillate heterostrophe apex so distinguishing a trait of this family. In form resembling $T$. acuticostata, Jeffreys. The trivial name now imposed suggests such affinity.

\section{Turbonilla terebrina, n.sp. Pl. VIII, Fig. 20.}

T. testa gracillima, multum attenuata, candida, nitida, perlævi, anfractibus 11, longitudinaliter lævissimi-costatis, interstitiis omnino lævibus, apertura oblonga, peristomate simplice. Long. 6, lat. 1.15 mm.

About the same size as the preceding, but a more solid, shining shell, with smoothly rounded ribs, scarcely elevated, and the interstices also quite smooth; mouth oblong, lip simple. Five specimens. The superficial likeness to a species of Terebra suggested the trivial name. It belongs to the typical genus Turbonilla proper, and is nearly allied to some European species.

\section{Turbonilla (Pyrgostelis) Emiliz, n.sp. Pl. VIII, Fig. 25.}

T. testa minuta, oblonga, cylindrica, candida, apice mamillari heterostropho, anfractibus 6, undique longitudinaliter recticostatis, interstitiis transversim arete tenuissimi striatis, apertura ovata, peristomate, paullum incrassato, margine columellari simplice. Long. $1 \cdot 75$, lat. $75 \mathrm{~mm}$.

A very small, straightly-whorled, white, semipellucid species, of which many specimens occurred in the last consignments of shellshingle, but which was not noticed in previous siftings. I am not quite satisfied with the location, though it seems to resemble in form such species as Pyrgostelis flexuosa, Jeffreys. Had a columellar plait been present, no doubt it would be relegated to Pyrgulina. I venture to associate with this little shell the christian name of Mrs. Abercrombie.

\section{Cingulina Archimedea, n.sp. Pl. VIII, Fig. 2.}

C. testa pyramidato-fusiformi, candida, concinna, solidiuscula, anfractibus 11, transversim spiraliter acute bicarinatis, interstitiis oblique rudi-lineatis, ultimo anfractu apud basim lævi, ad peripheriam angulato, apertura subquadrata, labro simplice. Long. 5, lat. 1.75 mm.

Three specimens, all precisely similar, of a pure white shell, with a slight bluish tinge in parts, spirally acutely twice keeled on the whorls, which would be in a perfect specimen eleven in number, but none of those before us have the apex complete; the keels are sharp and projecting. At the base the shell is smooth, the aperture is squarely angular, mouth simple. This species is the most sharply carinate of any Cingulinæ we have examined. The miniature serew-like appearance suggested the trivial name, after Archimedes, the celebrated Syracusan mathematician, inventor of the screw, who is reported to have taken for his model thereof the well-known Mediterranean shell Turritella terebra, L.

25. Phasianella minima, n.sp. Pl. VIII, Fig. 11.

P. testa minutissima, perforata, solidiuscula, alba, nitida, anfractibus 5, tumescentibus, ventricosis, lævissimis, rubro-punctatis et flammulatis, apud medium anfractus ultimi squarrose rubro-maculatis, 
maculis transversis, paucis, apud basim multipunctatis, apertura ovatorotunda, labro simplice. Long. $2 \mathrm{~mm}$. sp. maj., lat. $1 \mathrm{~mm}$.

A very minute shell, which I cannot exactly match with any pourtrayed and described in Pilsbry's exhaustive collaboration of the genus. ${ }^{1}$ It comes near to $P$. umbilicata, D'Orb., from Cuba and Florida, but would seem even more tumid than that species, while it is entirely smooth, with no impressed lines; the shell is perforate, solid, white, shining, very smooth, with five whorls; whorls extremely tumid and ventricose, impressed at the sutures, painted with a sprinkling of minute red dots, these most profuse at the base of the shell; a little below the lower half of the last whorl there is a transverse row of a few somewhat square, dark-red spots; the mouth is oval, outer lip simple.

Ten specimens, but mostly not full-grown.

\section{Tellina (Tellinella) thymares, n.sp. Pl. VIII, Fig. 9.}

T. testa delicatula, tenui, alba, subtrapeziformi, compressa, concentrice multi-costulata, margine dorsali declivi, serrulato, latere antico expanso rotundato, postico truncatulo, margine ventrali latus ad posticum contracto, deflexo. Long. 13, lat. $20 \mathrm{~mm}$.

A most delicate species, resembling in texture, but not in form, such species as Tellina perplexa or T. lyra, both of Hanley. The shell is trapezium-shaped, compressed, delicate white, thin, regularly concentrically closely ribbed, the dorsal margin sloping slightly, thus recalling the genus Tellidora, (e.g. T. crystallina), serrulate both posteriorly and anteriorly, the anterior side being roundly expansive, somewhat truncate posteriorly, the ventral margin contracted towards the posterior side.

The specific name is from the Greek $\theta v \mu a \dot{\rho} \eta s$, 'delicate.'

\section{EXPLANATION OF PLATE VIII.}

1. Bittium tenthrenoïs.

2. Cingulina Archimedea.

3. Cerithiopsis pulcherrima.

4. Rissoina pachystoma.

5. Oscilla Indica.

6. Miralda idalima.

7. Turbonilla Abercrombiei.

8. Cerithiopsis Sykesii.

9. Tellina thymares.

10. Aclis atemeles.

11. Phasianella minima.

12. Solarium homalaxis.

13. Odostomia syrnoloides.
14. Adeorbis vanikoroides.

15. Cerithiopsis rubricincta.

16. Syrnola metria.

17. 'Turbonilla sororia.

18. Aclis eoa.

19. Eulima dens-colubri.

20. Turbonilla terebrina.

21. Pyrgulina Edgarii.

22. Odostomia antelia.

23. Rissoina epentroma.

24. Pyrgulina pyrgomella.

25. Turbonilla Emiliæ.

26. Myonia gavisa.

1 Man. Conch., ser. I, vol. x, p. 162, ete. 


\section{$2 \mathrm{BHL}$ Biodiversity Heritage Library}

1896. "Descriptions of new species of minute marine shells from Bombay." Proceedings of the Malacological Society of London 2, 108-116.

View This Item Online: https://www.biodiversitylibrary.org/item/52043

Permalink: https://www.biodiversitylibrary.org/partpdf/50883

\section{Holding Institution}

Smithsonian Libraries

\section{Sponsored by}

Smithsonian

\section{Copyright \& Reuse}

Copyright Status: Public domain. The BHL considers that this work is no longer under copyright protection.

This document was created from content at the Biodiversity Heritage Library, the world's largest open access digital library for biodiversity literature and archives. Visit BHL at https://www.biodiversitylibrary.org. 